ORIGINAL ARTICLE

\title{
The Relationship between Body Mass Index and Urinary Creatinine in Adolescent Girls
}

\author{
Nita Andriani Lubis ${ }^{1}$, Geminsah Putra H. Siregar ${ }^{1}$, Mardan Ginting ${ }^{1}$ \\ ${ }^{1}$ Politeknik Kesehatan Kemenkes Medan
}

Corresponding E-mail : nita.andriani.lubis@gmail.com

\begin{abstract}
Adolscent girls phase (12-21 years) is a very important individual development segment, beginning with the maturation of physical and reproductive organs that characterize women of childbearing age. Body mass index (BMI) is one of indicator used to see women of childbearing age status related to pregnancy. Kidney damage causes an increase in urinary creatinine but high urinary creatinine does not necessarily indicate kidney damage. Our objective is to determine the relationship between BMI and urine creatinine in adolscent girls in several Medan health schools. We performed an observasional study with cross sectional design of 56 participants 19-21 old girls. 24 hours urine creatinine concentration was measured using jaffe reaction method. The highest average BMI value $\left(21.10 \mathrm{~kg} / \mathrm{m}^{2}\right.$ is the normal category $(75 \%)$, mean urine creatinine concentration $(1263,86 \mathrm{mg} / 24$ hour) is also normal category. Data analysis with spearman correlation between BMI and 24-hour urine creatinine level was not statistically different $(\mathrm{p}=0.140)$. High BMI values tend to have high 24-hour urine creatinine levels too, but statistically there was no significant relationship between 24-hour urine creatinine levels and BMI values in this study.
\end{abstract}

Keywords: Urinary creatinine, BMI, Late adolescence 


\section{INTRODUCTION}

Urinary creatinine concentration are between 1.1 - $1.64 \%$ per day. Normally, urine creatinine excretion varies every day, the cause is largely unknown (Heymsfield et.al, 2009). Previous results have found that creatinine and albumin are biomarkers of acute and chronic kidney disease with more accurate examination of 24-hour urine measurements. ${ }^{25}$

Adolscent girls belongs to women of childbearing age. Nutritional status of woman can be used to see their health. The nutritional status can be assessed from the body mass index (BMI) value. Increased BMI has been shown to increase the risk of developing chronic kidney disease. Another study stated that body mass index had a significant correlation with glomerular filtration rate in obese students at Sam Ratulangi University medical school. $^{4}$

This study aims to determine the relationship of body mass index with adolscent girls urine creatinine in several health schools in the city of Medan, North Sumatera.

\section{METHODS}

This study was used a cross sectional design in a group of adolescent girls aged 18-21 years with a consecutive sampling method.

This research was conducted from January to July 2018 in 3 (three) health colleges registered at Kemenristek Dikti (STIKES Binalita TA Sudama, STIKES Widya Husada, and STIKES Audi Husada).

There are 56 people selected subjects who met the criteriaand they were given an explanation about this study, measured their height and weight, and were required to put their urine for 24 hours into a labeled container. A 24-hour urine sample of all study subjects was taken to the integrated laboratory of Poltekkes
Kemenkes Medan and creatinine levels were measured. The 24-hour urine creatinine examination was analized by photometer $5010+$ with the principle of reaction.

This research has passed the ethical review from the health commission ethics institute of the Poltekkes Kemenkes Medan.

\section{RESULTS}

Frequency distribution of subjects based on the characteristics of age, religion, institution, and $\mathrm{BMI}$ in table 1.

Table 1. Distribution of Research Subjects Based on Subject Characteristics.

\begin{tabular}{|c|c|c|}
\hline Characteristics & $\mathbf{N}$ & $\%$ \\
\hline \multicolumn{3}{|l|}{ Age (years) } \\
\hline 19 & 1 & 1.8 \\
\hline 20 & 28 & 50 \\
\hline 21 & 27 & 48,2 \\
\hline \multicolumn{3}{|l|}{ Religion } \\
\hline Islam & 46 & 82,1 \\
\hline Kristen & 10 & 17,9 \\
\hline \multicolumn{3}{|l|}{ Institution } \\
\hline STIKES & & \\
\hline Sudama & 15 & 26,8 \\
\hline STIKES & & \\
\hline Husada & 18 & 32,1 \\
\hline STIKES & & \\
\hline Husada & 23 & 41,1 \\
\hline \multicolumn{3}{|l|}{ BMI } \\
\hline Underweight & 3 & 5,4 \\
\hline Normal & 42 & 75 \\
\hline Overweight & 5 & 8,9 \\
\hline Obese & 6 & 10,7 \\
\hline
\end{tabular}

Based on the most frequency distribution, age 20 years $(50 \%)$, Islamic religion (82.1\%), STIKES Audi husada (41.1\%), and normal BMI (75\%).

The results of mean creatinine levels for the underweight group was 647,97; normoweight was 1971,74; overweight was 3502,96; and obese 2120,96. 
Table.2. Distribution of 24-hour Urine Creatinine Levels

\begin{tabular}{l|c|c|c|c}
\hline \multicolumn{1}{c|}{ BMI } & $\begin{array}{c}\text { Mean of } \\
\text { Urine } \\
\text { Creatinine }\end{array}$ & SD & $\mathbf{n}$ & $\mathbf{p}$ \\
\hline Underweight & 647,97 & 461,47 & 3 & 0,00 \\
Normal & 1971,74 & 1601,70 & 42 & \\
Overweight & 3502,96 & 978,98 & 4 & \\
Obese & 2120,96 & 1005,08 & 7 & \\
\hline
\end{tabular}

Table.3. Analysis of Spearman about Correlation Between BMI and Urinary Creatinine

\begin{tabular}{llrr}
\hline Variable & & BMI & \multicolumn{1}{c}{$\begin{array}{c}\text { Urinary } \\
\text { Creatinine }\end{array}$} \\
\hline BMI & Correlation & 1 & 0,241 \\
& Coefficient & & 0,073 \\
& Sig.(2 tailed) & & 56 \\
& $\mathrm{~N}$ & 56 & 1 \\
$\begin{array}{l}\text { Urineary } \\
\text { creatinine }\end{array}$ & Correlation & 0,241 & \\
& Coefficient & & \\
& Sig.(2 tailed) & 0,073 & \\
& $\mathrm{~N}$ & 56 & 56 \\
\hline
\end{tabular}

There is no significant relationship between urine creatinine level and BMI (p>0.05), with a correlation coefficient of 0.241 .

\section{DISCUSSION}

Statistical analysis performed by the Kruskal wallis test showed significant results with a value of $p<0.05$. The differences in urine creatinine levels in each subjects were strongly influenced by 24-hour urine volume. The 24-hour urine volume is influenced by the amount of fluid intake for 24 hours, the amount of muscle mass and the type of activity in 24 hours.

Research on Stener-Asidu et.al. in 101 male and female athletes at the University of Ghana stated physical exercise changed the amount of muscle mass in which the research subjects most BMI values were normal. ${ }^{1}$ In addition, the 24-hour urine volume that were different from each subjects was also greatly affected the 24-hour urine creatinine levels. This 24-hour urine volume is different from each subjects due to the differences in type and duration of physical activity. The results showed that there was no significant relationship between BMI and urine creatinine levels. This outcome may be due to differences in the number of frequency distributions of subjects based on the BMI category, where groups with normal BMI were more numerous than others, so statistically results were not different. The results showed that large and fluid intake for 24 hours. This is in accordance with Baxmann et.al's research, 2008 which stated that the mean values of serum and urine creatinine differed significantly between groups with moderate/intense physical activity and mild activity groups. ${ }^{5}$ BMI values tended to have a large 24-hour urine creatinine level.

\section{CONCLUSION}

Large BMI values tend to have a large 24-hour urine creatinine level, but statistically do not have a significant relationship.

\section{REFERENCES}

1. Ali M, Asrori, M. Psikologi Remaja. Jakarta: PT.Bumi Aksara.2012; 108-113.

2. Almatsier S, Susirah S, Moesijanti S. Gizi Seimbang Dalam Daur Kehidupan. Jakarta: PT.Gramedia Pustaka Utama.2011; 159-195.

3. Andri F, Hurmaly T.Diet Sehat Khusus Remaja.Yogyakarta: Khitah Publishing.2013.

4. Baladraf F, Syrachmanto EF, Moeis ES. Hubungan Indeks Massa Tubuh Dengan Laju Filtrasi Glomerulus pada Mahasiswa Dengan Obesitas di Fakultas Kedokteran Universitas Sam Ratulangi. Jurnal eBiomedik.2013;1(1), 246-251. 
5. Baxmann AC, Ahmed MS, Marquez NC, Menon VB ,Pereira $\mathrm{AB}$, Krisztajn GM ,et. al. Influence of Muscle Mass and Physical Activityon Serum and Urinary Creatinine and Serum Cystatin C.Clin Jam Soc Nephrol. 2008;(3),348-354.

6. Elistina. Penentuan volume urin 24 jam berdasarkan kadar kreatinin dalam urin. Prosiding pertemuan dan presentasi ilmiah fungsional teknis non peneliti. ISSN: 14105381.2006.

7. Ernawati F, Rosmalina Y, Permanasari Y. Pengaruh Asupan Protein Ibu Hamil dan Panjang Badan Bayi Lahir terhadap Kejadian Stunting pada anak usia 12 bulan di Kabupaten Bogor. Pusat Teknologi Terapan Kesehatan dan Epidemiologi Klinik. Badan Litbangkes, Kemenkes RI. Penelitian Gizi dan Makanan.2013; 36(1), 1-11

8. Gerchman F,Tong J,Utzschneider KM,Zraika S,Udayasankar J, Mcneely MJ, et.al.Body Mass Index Is associated with Increased Creatinine Clearence by Mechanism Independent of Body Fat Distribution.J.Clin Endocrinol Metab.2009;94(10),3781-3788.

9. Heymsfield BS, Artega MDC, Mc Manus BSJ,Smith RD,\& Moffitt S.Measurement of Muscle Mass in Humans: Validity of the 24-Hour Urinary Creatinine Method.The American Journal of Clinical Nutrition. 2009;37,478-494.

10. Heri L. Info Demografi, LD-FE Universitas Indonesia, Jakarta.2017;3-9.

11. Hurlock EB. Psikologi Perkembangan Suatu Pendekatan Sepanjang Rentang
Kehidupan.Jakarta:Erlangga.2003; 37-41

12. Infodatin. Pusat Data dan Informasi Kementerian Kesehatan RI. Situasi Kesehatan Reproduksi Remaja. ISSN 2442-7659.2015;3-6

13. Kementrian Kesehatan Republik Indonesia. Profil Kesehatan Indonesia Tahun 2013, Jakarta.2014;124-127.

14. Lesley A, Stevens MD, Andrew S, Levey MD. Penyakit Ginjal Kronis, Dialisis, dan Transplantasi .2010; (3).

15. Latifah L, Anggraeni MD. Pengalaman Mahasiswa Pria dalam Praktek Profesi Keperawatan Maternitas yang Bias Gender, Jurnal Keperawatan Soedirman, 2014; 9(3).

16. Novitasary MD, Mayudu N, Kewengian, SES. Hubungan Antara Aktivitas Fisik Dengan Obesitas Pada Wanita Usia Subur Peserta Jamkesmas di Puskesmas Wonorogo Kecamatan Singkil Manado. Jurnal e-Biomedik. 2013;1(2), 1040 .

17. Nusindo RCC. Pedoman kerja reagen diagnostik ST. Reagen/ Rajawwali Nusindo diagnostik.2016;2-4.

18. Soeparman. Ilmu penyakit dalam Jilid ii. Jakarta: Balai Penerbit FKUI.2001;148-152.

19. Sabarudin A, Wulandari ERN, Sulistyarti H.Sequential InjectionFlow Reversal Mixing (SI-FRM) Untuk Penenyuan Kreatinin Dalam Urin. Jurnal MIPA.2012; 35 (2), 157-164.

20. Sinceler SJ, Visser FW, Krikken JA, Stegeman CA, Homan van der Heide JJ, Navis G.Higer Body Mass Index Is Associated With Higher Fractional Creatinine Excretion In Healthy Subjects 
Nephrol

Dial

Transplant.2011;16,3181-3188.

21. Steiner-Asiedu M,Vickar J,Vuvor F,Agbemafle I, Tahiru YM. Urine Creatinine and Anthropometric Indicies of Sportsmen and Women. Biomedical and Biotechnology Reasearch Journal. 2017;1,134140.

22. Sulistyoningsih. Gizi Untuk Kesehatan Ibu dan Anak. Yogyakarta: PT Graha Ilmu.2011;

23. Susan LA, Macdonald IA, Roche HM. Metabolisme Zat Gizi.Jakarta: Penerbit Buku Kedokteran EGC.2016;

24. Tzeng YL, Chen JZ, Tu HC, Tsai TW. Role strain of different gender nursing students in obstericts practice: a comparative study. Jurnal of Nursing Research. 2009;17(1),1-9

25. Waikar SS,Sabbisetti VS, Bonventre JV. Normalization of Urinary Biomarkers to Creatinine During Changes in Glomerular Filtration Rate. Kidney International.2010; 78,486-494.

26. Wyss M, Kaddrah-Daouk R. Creatine and Creatinine Metabolism. Physiological Reviews.2000;80(3),1109-1113

27. Yohan HOP, Waleleng BJ, Wanita F. Hubungan Antara Indeks Massa Tubuh Dengan Estimasi Laju Filtrasi Kedokteran University, Sam Ratungi Manado. Repository Universitas Sam Ratulangi.2014;1(2),1-10 